\title{
Natural radioactivity levels of some medicinal plants commonly used in Ghana
}

\author{
Lordford Tettey-Larbi ${ }^{1,2^{*}}$, Emmanuel Ofori Darko ${ }^{1,2}$, Cyril Schandorf ${ }^{1}$ and Alfred Ampomah Appiah ${ }^{3}$
}

\begin{abstract}
Natural radioactivity levels in some selected medicinal plants commonly used in Ghana from the Centre for Scientific Research into Plant Medicine were investigated to determine the activity concentration and the annual committed effective dose due to naturally occurring radionuclides of ${ }^{238} \mathrm{U},{ }^{232} \mathrm{Th}$ and ${ }^{40} \mathrm{~K}$. The activity concentration was determined using gamma-ray spectrometry. The results of the analysis indicated an average activity concentration of ${ }^{238} \mathrm{U},{ }^{232} \mathrm{Th}$ and ${ }^{40} \mathrm{~K}$ in the medicinal plants to be $31.8 \pm 2.8 \mathrm{~Bq} \mathrm{~kg}^{-1}, 56.2 \pm 2.3 \mathrm{~Bq} \mathrm{~kg}^{-1}$ and $839.8 \pm 11.9$ $\mathrm{Bq} \mathrm{kg}^{-1}$ respectively. Khaya ivorensis recorded the highest activity concentration of ${ }^{238} \mathrm{U}$ and ${ }^{232} \mathrm{Th}$ while Lippia multiflora recorded the highest activity concentrations of ${ }^{40} \mathrm{~K}$. The total annual committed effective doses ranged from $0.026 \pm 0.001$ to $0.042 \pm 0.002 \mathrm{mSv}^{-1}$ with an average value of $0.035 \pm 0.001 \mathrm{mSv}^{-1}$. The average annual committed effective dose due to ingestion of the natural radionuclides in the medicinal plant samples were far below the world average annual committed effective dose of $0.3 \mathrm{mSv}^{-1}$ for ingestion of natural radionuclides provided in UNSCEAR 2000 report. Therefore, the radiological hazard associated with intake of the natural radionuclides in the medicinal plants is insignificant. The results provide baseline values which may be useful in establishing rules and regulations relating to radiation protection as well as developing standards and guidelines for the use of medicinal or herbal plants to the appropriate authorities.
\end{abstract}

Keywords: Medicinal plants, Natural radioactivity, Gamma-ray spectrometry, Annual committed effective dose

\section{Introduction}

Naturally occurring radioactive materials (NORMS) are found in every constituent of the environment; air, water, soil, food and in humans. According to the International Food Safety Authorities Network (INFOSAN 2011), plants used as food commonly have ${ }^{40} \mathrm{~K},{ }^{232} \mathrm{Th}$ and ${ }^{238} \mathrm{U}$ and their progenies. It is expected that likewise would be found in plants used for medicinal purposes since plants are the primary pathway of natural radionuclides entering into the human body through the food chain. Radionuclides and their decay products from ${ }^{238} \mathrm{U}$ and ${ }^{232} \mathrm{Th}$ series together with ${ }^{40} \mathrm{~K}$ are terrestrial primordial radionuclides, which originated from the earth's crust and are the sources of natural radioactivity in the environment (Kessaratikoon and Awaekechi 2008).

\footnotetext{
* Correspondence: lordford4@yahoo.com

'Graduate School of Nuclear and Allied Sciences, University of Ghana, P. O.

Box AE 1, Atomic Energy, Kwabenya, Accra, Ghana

${ }^{2}$ Radiation Protection Institute, Ghana Atomic Energy Commission, Box LG

80, Legon, Accra, Ghana

Full list of author information is available at the end of the article
}

All over the world, raw parts of plants and their extracts are used in the medicinal products. It is also estimated that $25 \%$ of modern medicines are derived from medicinal plants of which most of them are flowering plants (Gurib-Fakim and Kasilo 2010). There are over 250,000 flowering plant species that serve as resources for the production of new drugs, orthodox or traditional. The World Health Organisation (WHO) define traditional medicine as comprising therapeutic practices that have been in existence, often for hundreds of years, before the development and spread of modern medicine and are still in use today (WHO 1991).

A survey by the WHO indicates that about $70-80 \%$ of the world population rely on traditional medicine mainly from plant sources due to the increasing emphasis on advocacy on Primary Health Care or Basic Health Care (Brown 1992); (WHO 1998). In Ghana, 70\% of the populations rely on herbal medicines where the Practitioner to Patient ratio is $1: 400$ in case of traditional medicine as against 1:12000 in modern medicine even though the lack of scientific proof of the effects of traditional medicine has 
often made scientists doubt their efficacy (Serfor-Armah et al. 2003); (Haq 2004); (Owusu-Afriyie 2005). However, plant based medicines present a high efficacy, safety and lesser side effects and offer remedy for age-related disorders like memory loss, osteoporosis, immune disorders for which no modern medicine is available (Kamboj 2000).

The therapeutic effect of these medicinal plants for the treatment of various diseases is based on the organic constituent (such as essential oil, vitamins, glycosides, etc.) present in them (Desideri et al. 2009), although, certain inorganic elements (example $\mathrm{Al}, \mathrm{Br}, \mathrm{Ca}, \mathrm{Cl}, \mathrm{Mn}, \mathrm{Mg}$, etc.) have been considered as essential in the formation of active constituent which are responsible for the curative properties of the medicinal plants (Serfor-Armah et al. 2001). These stable inorganic elements like the unstable ones (radioactive element) find their way into these plants during the process of photosynthesis. Natural radionuclides are transferred and cycles through natural processes and between the various environmental compartment by entering into the ecosystem and food chain through direct or indirect contamination of natural radionuclides (Adewumi 2011). This processes involving photosynthesis include the absorption of soluble radionuclides in soil-water by root uptake, direct deposition from the atmosphere and resuspended natural radionuclide from the soil. The main factors controlling the rate of plant root uptake of natural radionuclides are the uptake potential for different natural radionuclides and the availability of natural radionuclides in the soil. The rate of natural radionuclides uptake is highly dependent on the activity concentration in the soil. Also, the root uptake depends on soil properties such as $\mathrm{pH}$, mineralogical composition, organic matter content and nutrient status as well as metabolic and physiological characteristic of the plant species (IAEA 2006). Obviously, plants uptake of radionuclides is one of many vectors for the migration of natural radionuclides into humans from the environment via the food chain.

The study of the radioactivity levels of plants in the environment are of interest within ecological and plant evolution under certain conditions of geochemical point of view and adaptation and it thus provide information in the monitoring of environmental radioactivity (Mukhammedov and Tillaeva 2005). The study of NORMS in plants is also not only important because of the risk associated with it but also from the fact that some of them can be used as biochemical tracer in the human food chain.

The role of NORMS in animal and plant metabolism has long been established and available in literature, but the effect and influence of these NORMS on administration of medicinal plants had received relatively little attention without due regard to possible side effects possibly because medicinal plants or herbal plants are not considered in the group of edible plants that have been studied in the past by nutritionist, although many edible plants used as spices or fruits such as ginger, onion, pawpaw and mango etc., have medicinal properties and the ingestion of NORMS through the use of medicinal plants had not been recognized or considered significant in terms of quantity. These factors have therefore contributed little or no information on the levels of the natural radioactive materials constituent of these medicinal or herbal plants preparation and their extracts in Ghana.

Epidemiological studies have not demonstrated adverse health effects in individuals exposed to small doses $(<0.1 \mathrm{~Sv})$ delivered in a period of many years with the exception of radiogenic health effects (primarily cancer) which is evident in epidemiological studies for only doses exceeding 0.05-0.1 Sv delivered at high dose rates (HPS 2004). However the linear non-threshold (LNT) model indicates levels of risk to all levels of radiation (ICRP 1991, 2005). Although, some scientists believe that since humans evolved and survived through this evolutionalised environment which consists of some levels of radiation, some low levels of radiation are beneficial to the human (Hormesis) (Cuttler 2004).

Medicinal plants are administered in their raw form or in formulations such as solutions, tablets or capsules. Undoubtedly, the activity concentrations of NORMS in herbal formulations are quite lower than in the raw plants due to the preparation processes which inevitably remove some of the radionuclides. The health effects of radiation exposures to NORMS from intake of medicinal plants and herbal preparations in relation to the levels of NORMS in medicinal plants may be associated with most forms of leukemia and with cancer of many organs such as the bone, lung, breast and thyroid in the long term, but not with all organs including prostate. Example; approximately $10-15 \%$ of ${ }^{210} \mathrm{~Pb}$ and ${ }^{214} \mathrm{~Pb}$ ions, $99 \%$ of ${ }^{226} \mathrm{Ra}$ and ${ }^{228} \mathrm{Ra},{ }^{214} \mathrm{Bi}$ (bone seeker) and ${ }^{210} \mathrm{Po}$ (soluble) reaches the blood and/or the lung fluid stream and are distributed to the whole body and exchanged with calcium in the mineral of skeletal tissues thereby making blood, bone and lung critical organs (UNSCEAR 1988, 2000); (Cember and Johnson 2009). Also, ${ }^{238} \mathrm{U}$ has affinity for electron donor (e.g. oxygen) and therefore deposits itself in the tissues of the lung and lining on the bones marrows which can lead to cancer of the blood (leukemia). ${ }^{232} \mathrm{Th}$ which is also an alpha particle emitter settles in the lining of the bones which can lead to bone cancer (Cember and Johnson 2009). Although ${ }^{40} \mathrm{~K}$ is not considered to be of radiological significance, the body's control system of blood pressure and volume is dependent on the activity concentration of potassium in the body and an abnormality in the control of this activity concentration level in the body by the body system presents a general potential for High Blood Pressure and subsequent cancer induction with a lifetime cancer Mortality Risk of $0814 \mathrm{~Bq}^{-1}$ for ingestion 
(ANL 2005). However, studies have shown that the total amount of potassium in the human body is maintained constant at a fixed body mass. The activity concentration of $\mathrm{K}-40$ in potassium in plants extracts and raws is not different from those in foods or in the human body. Intake of additional potassium through food intake simply results in a reduction in the biological half-life of potassium in the body and resultantly no increase in the dose from K-40. This implies that potassium is homeostatic within the body (Tahir and Alaamer 2008); (Tahir et al. 2010).

The objectives of this study are to determine the specific activity concentrations and the annual effective doses due to ingestion of NORM due to ${ }^{238} \mathrm{U},{ }^{232} \mathrm{Th}$ and ${ }^{40} \mathrm{~K}$ present in some selected medicinal plants commonly used in Ghana from the Centre for Scientific Research into Plant Medicine (CSRPM) at Mampong-Akuapem in the Eastern Region and to assess the radiological risk associated with the use of these medicinal plants.

\section{Materials and methods The sampling area}

The choice of the sampling site was an important factor in this study. Prominence was placed on the choice of a clinic that has the highest production and use of medicinal plants in Ghana. The Centre for Scientific Research into Plant Medicine (CSRPM) was established in 1975 by the Government of Ghana through the pioneering work of Dr. Oku Ampofo, a Ghanaian allopathic medical practitioner. Today, it is a leading research institution in Africa and its core business is into Research and Development of herbal medicines in Ghana and Africa as a whole (CSRPM 2011).

The Centre is located at $5^{\circ} 55^{\prime} 04.58^{\prime \prime} \mathrm{N}$ and $0^{\circ}$ $08^{\prime} 02.89^{\prime \prime} \mathrm{W}$ at an elevation of $1,488 \mathrm{ft}$ and an eye altitude of $1,575 \mathrm{ft}$ (Google Earth 2012) in the mountainous forest savanna vegetation area of Mampong, Eastern Region of Ghana. The centre is off Mampong-Akropong road, which lies within the wet semi-equatorial zone, characterized by double maxima rainfall in June and October with relatively low temperatures and high humidity through the year.

The Centre offers the following services: clinical laboratory services, production and dispensing of herbal medicines to patients, raising of medicinal plant seedlings for sale to out growers, formulation and production of herbal extracts for industries, safety, efficacy and quality assessment of herbal products from manufacturers and herbal practitioners and provision of library and internet café for research into plant medicine.

\section{Sample collection}

Three samples (1 kg each) of Eight (8) different medicinal plants parts samples (Table 1) used at the Centre were collected between the month of October and December, marking the end of the raining season and the beginning of the dry season which allows for fresh sampling and a good weather condition for drying the samples. The medical use of these plant parts is also shown in Table 1. The samples were transferred in labeled polyethylene bags from the Centre to the laboratory.

\section{Sample preparation}

The samples were open air dried on trays for a period of one week and then oven dried at a temperature of $105^{\circ} \mathrm{C}$ $\left( \pm 5^{\circ} \mathrm{C}\right)$ for 2 to 4 hours at the laboratory. The oven dried samples were then grounded into fine powder with a stainless steel ball grinder. The prepared samples, in powdered form, were packed into weighed one (1) liter Marinelli plastic beaker, hermetically sealed, reweighed and stored prior to counting (Scheibel and Appoloni 2007); (Changizi et al. 2010); (Olatunde et al. 2011). The containers were sealed to avoid any possibility of outgassing of radon and kept for a period of 1 month to make sure the samples attained radioactive equilibrium between Ra-226 and its decay products in the uranium series, and Ra-228 and its decay products in the thorium series (Tahir and Alaamer 2009).

Table 1 Physical data of plant samples used

\begin{tabular}{|c|c|c|c|}
\hline Name of plant sample & Local name (Akan) & Part of plant sampled & Medical use \\
\hline Lippia multiflora & Saresonunum & Leaves & Hypertension, lactation failure, insomia, conjunctivitis, \\
\hline Croton membranaceus & None & Roots & Prostatic hypertrophy, measles \\
\hline Cassia sieberiana & $\begin{array}{l}\text { Prongkese } \\
\text { Poto rodom }\end{array}$ & Root-bark & Menstrual pain, abdominal pain, (Pain killer) \\
\hline Bridelia ferruginea & Opan fufuo & Leaves & Hypertension, diabetes \\
\hline Mondia whitei & Mondi & Roots & Improve sex hormones (low sperm count), STD, Stroke \\
\hline Blighia sapida & $\begin{array}{l}\text { Takwa dua } \\
\text { Ankye fitaa }\end{array}$ & Stem-bark & Migraine, diarrhoea \\
\hline Alstonia boonei & Nyame dua & Stem-bark & Malaria, rheumatism, boil \\
\hline Khaya ivorensis & Odupon & Stem-bark & Fever, anemia \\
\hline
\end{tabular}




\section{Analysis of the medicinal plant samples}

The samples were counted using a gamma-ray spectrometry. The gamma-ray spectrometry system consists of an N-type high purity germanium (HPGe) detector Model GR 2518 (Canberra Industries Incorporated) with a relative efficiency of Twenty-five percent (25\%) to NaI detector, $1.8 \mathrm{keV}$ energy resolution (FWHM) at energy peak of $1333 \mathrm{keV}$ of ${ }^{60} \mathrm{Co}$ isotope, a peak-to-Compton ration of 55:1. The bias voltage of $-3000 \mathrm{~V}$ was supplied by a HV Power Supply (Model 13103) through an Uninterrupted Power Supply (UPS). The detector was cooled in liquid nitrogen at $-196^{\circ} \mathrm{C}(77 \mathrm{~K})$ provided in a 25 liter Dewar with ambient temperature around the detector being between $16^{\circ} \mathrm{C}$ and $27^{\circ} \mathrm{C}$. The detector was connected to a Spectroscopy Amplifier (model 2020, Canberra Industries Incorporated) and a computer based PCA-MR 8192 ACCUSPEC Multi-Channel Analyzer (MCA) and a Microsoft soft window software ORTEC MAESTRO-32 for spectrum acquisition, evaluation and analysis. The detector was mounted in a cylindrical lead shield with internal diameter of $24 \mathrm{~cm}$, thickness of $5 \mathrm{~cm}$ and a height of $60 \mathrm{~cm}$. The lead shield consist of a $0.3 \mathrm{~cm}$ thick each of various layers of copper, cadmium and plexiglass.

The energy and efficiency calibration of the system was carried out before sample analysis using the multinuclide reference standard solution supplied by the International Atomic Energy Agency, IAEA. This was to enable identification and quantification of the radionuclides. The standard and the sample were counted for a period of 36,000 seconds to acquire spectral data for a better counting statistics and evaluation. The activity concentration of ${ }^{238} \mathrm{U},{ }^{232} \mathrm{Th}$ and ${ }^{40} \mathrm{~K}$ were determined after correction for background and inhomogeneities (Oresengun et al. 1993); (Gilmore and Hemingway 1995).

The specific activity concentration of ${ }^{238} \mathrm{U},{ }^{232} \mathrm{Th}$ and ${ }^{40} \mathrm{~K}$ in the medicinal plants were determined from the quantitative analysis of the spectra acquired from the Gamma-ray spectrometry using the Gamma-ray spectrum analysis software, Ortec MAESTRO-32 at specific energies. ${ }^{238} \mathrm{U}$ was calculated from the average of ${ }^{214} \mathrm{~Pb}$ at energies of $251.9 \mathrm{keV}$ and $295.2 \mathrm{keV}$ and ${ }^{214} \mathrm{Bi}$ at energies of $609.3 \mathrm{keV}$ and $1764.5 \mathrm{keV} .{ }^{232} \mathrm{Th}$ was determined from the average of ${ }^{208} \mathrm{Tl}$ at energies of $2614.5 \mathrm{keV}$ and $583.2 \mathrm{keV},{ }^{212} \mathrm{~Pb}$ at the energy of $238.6 \mathrm{keV}$ and ${ }^{228} \mathrm{Ac}$ at the energy of $911.2 \mathrm{keV}$ and ${ }^{40} \mathrm{~K}$ at $1460.0 \mathrm{keV}$.

The specific activity $\left(A_{s p}(E, i)\right.$ in $\left.\mathrm{Bq} \mathrm{kg}{ }^{-1}\right)$ of the radionuclide $i$ in the samples were calculated after decay correction using the expression in equation (1) (Ebaid 2010).

$$
\mathrm{A}_{\mathrm{sp}}(\mathrm{E}, \mathrm{i})=\frac{\mathrm{N}_{\mathrm{sam}}(\mathrm{E}, \mathrm{i})}{\varepsilon_{\gamma}(\mathrm{E}) \cdot \mathrm{T}_{\mathrm{c}} \cdot \mathrm{P}_{\gamma}(\mathrm{E}, \mathrm{i}) \cdot \mathrm{M}_{\mathrm{sam}}}
$$

where; $N_{\text {sam }}\left(\mathrm{E}_{\mathrm{j}}\right)$ is the net counts for the radionuclide $i$ at energy $E, \varepsilon_{\gamma}(E)$ is the photopeak efficiency at energy
$E, T_{c}$ is the counting live-time (s), $\mathrm{P \gamma}(\mathrm{E}, \mathrm{i})$ is the gamma emission probability of the radionuclide $i$ for a transition at energy $E, M_{\text {sam }}$ is the dry-weight of samples $(\mathrm{kg})$.

Having obtained the values for the specific activity concentrations of the individual naturally occurring radionuclides in the medicinal plants, the average annual committed effective dose, $E_{\text {ave }}$, for ingestion of NORMS in the medicinal plants were calculated using the expression in equation (2).

$$
E_{\text {ave }}=\mathrm{I}_{p} \cdot D C F_{\text {ing }} \cdot A_{s p}
$$

Where $D C F_{\text {ing }}$ is the dose convection factor for ingestion, for each radionuclide (i.e., $4.5 \times 10^{-5} \mathrm{mSv} \mathrm{Bq}^{-1}$, $2.3 \times 10^{-4} \mathrm{mSv} \mathrm{Bq}^{-1}$ and $6.2 \times 10^{-6} \mathrm{mSv} \mathrm{Bq}^{-1}$ for ${ }^{238} \mathrm{U}^{232} \mathrm{Th}$ and ${ }^{40} \mathrm{~K}$ respectively for an adult (UNSCEAR 2000), $I_{p}$ is the consumption rate from intake of NORMS in medicinal plants and $A_{s p}$ is the activity concentration in the plant sample.

Generally in Ghana, the average percentage plant material in grams used in herbal preparation or products is five percent $(5 \%)$ of which the average dosage is two (2) table spoons full $(30 \mathrm{ml})$, three (3) times daily (Personal communication, Appiah A. A. 2012). This means that, for every $100 \mathrm{ml}$ of herbal product, $5 \mathrm{~g}$ of plant material is used and also since one (1) table spoon full is equivalent to $15 \mathrm{ml}$, two (2) table spoons full, three (3) times daily is equivalent to $90 \mathrm{ml}$. Therefore, on the basis of this information and the non-availability of a well-accepted consumption rate for medicinal plants, a consumption rate of $1.8 \mathrm{~kg} \mathrm{yr}^{-1}$ was assumed for all the medicinal plants used in this study, assuming that a patient needs $100 \mathrm{ml}^{\text {day }}{ }^{-1}$ (an upper average dosage) of the herbal preparation or product during the treatment period.

\section{Results and discussions}

Activity concentrations in the medicinal plants

The activity concentration of ${ }^{238} \mathrm{U}$ in the medicinal plants ranges from $20.42 \pm 1.99$ to $46.89 \pm 2.13 \mathrm{~Bq} \mathrm{~kg}{ }^{-1}$ with an average value of $31.78 \pm 2.80 \mathrm{~Bq} \mathrm{~kg}^{-1}$. The highest activity concentration of ${ }^{238} \mathrm{U}$ was recorded for Khaya ivorensis whilst Blighia sapida had the lowest activity concentration. For the activity concentration of ${ }^{232} \mathrm{Th}$, it varied from $42.02 \pm 1.71$ to $70.60 \pm 3.37 \mathrm{~Bq} \mathrm{~kg}^{-1}$ with an average value of $56.16 \pm 2.32 \mathrm{~Bq} \mathrm{~kg}^{-1}$ in the medicinal plants. The highest and lowest activity concentration was recorded for Khaya ivorensis and Blighia sapida respectively. ${ }^{40} \mathrm{~K}$ recorded the highest activity concentration in all the medicinal plants compared to the activity concentration of ${ }^{238} \mathrm{U}$ and ${ }^{232} \mathrm{Th}$ observed. The activity concentration varied from $566.35 \pm 7.90$ to $1093.11 \pm 17.02 \mathrm{~Bq} \mathrm{~kg}^{-1}$ with an average value of $839.80 \pm 11.86 \mathrm{~Bq} \mathrm{~kg}$. Lippia multiflora recorded the highest activity concentration with the second highest 
Table 2 Activity concentrations and average annual committed effective doses of ${ }^{238} \mathrm{U},{ }^{232} \mathrm{Th}$ and ${ }^{40} \mathrm{~K}$ in the medicinal plant samples

\begin{tabular}{|c|c|c|c|c|}
\hline \multirow[t]{2}{*}{ Sample } & \multicolumn{3}{|c|}{ Activity concentration (Bq kg $\left.{ }^{-1}\right)$} & \multirow{2}{*}{$\begin{array}{l}\text { Average annual committed } \\
\left.\text { Effective dose ( } \mathrm{mSv} \mathrm{a}^{-1}\right)\end{array}$} \\
\hline & ${ }^{238} \mathrm{U}$ & ${ }^{232} \mathrm{Th}$ & ${ }^{40} \mathrm{~K}$ & \\
\hline Lippia multiflora & $32.2 \pm 3.1$ & $65.6 \pm 3.1$ & $1093.1 \pm 13.1$ & $0.014 \pm 0.002$ \\
\hline Croton membranaceus & $36.1 \pm 2.8$ & $65.5 \pm 2.4$ & $808.8 \pm 12.9$ & $0.013 \pm 0.002$ \\
\hline Cassia sieberiana & $25.8 \pm 2.2$ & $43.0 \pm 1.7$ & $566.4 \pm 7.9$ & $0.009 \pm 0.001$ \\
\hline Bridelia ferruginea & $32.6 \pm 2.6$ & $53.3 \pm 1.8$ & $993.4 \pm 12.6$ & $0.012 \pm 0.001$ \\
\hline Mondia whitei & $25.9 \pm 3.0$ & $46.9 \pm 2.2$ & $961.1 \pm 11.2$ & $0.011 \pm 0.001$ \\
\hline Blighia sapida & $20.4 \pm 2.0$ & $42.0 \pm 2.0$ & $625.5 \pm 10.4$ & $0.009 \pm 0.001$ \\
\hline Alstonia boonei & $34.4 \pm 4.6$ & $62.4 \pm 3.4$ & $911.1 \pm 17.0$ & $0.013 \pm 0.001$ \\
\hline Khaya ivorensis & $46.9 \pm 2.1$ & $70.6 \pm 1.9$ & $759.1 \pm 9.9$ & $0.014 \pm 0.002$ \\
\hline
\end{tabular}

being Bridelia ferruginea whilst the lowest was record in Cassia sieberiana. The activity concentrations of the various medicinal plants are presented in Table 2 and the activity concentration have been compared and represented in Figure 1.

The variation of the activity concentration of ${ }^{238} \mathrm{U}$, ${ }^{232} \mathrm{Th}$, and ${ }^{40} \mathrm{~K}$ in the different medicinal plant samples may be due to the fact that, the activity concentrations of ${ }^{238} \mathrm{U},{ }^{232} \mathrm{Th}$, and ${ }^{40} \mathrm{~K}$ differ geographically from one soil of cultivation to another and some plants also absorbs certain elements more than others. Observably, the activity concentration of these radionuclides also varies with their half-life. Thus, the longer the half-life, the higher is the activity concentration of the radionuclides. This means that, the ratio of ${ }^{232} \mathrm{Th}$ to ${ }^{238} \mathrm{U}$ in these medicinal plant samples would to be greater than one as reported for other environmental samples (Miah et al. 1998). However, the activity concentration of ${ }^{40} \mathrm{~K}$ is usually high compared to ${ }^{238} \mathrm{U}$ and ${ }^{232} \mathrm{Th}$ and forms an integral part of all organic constituents. ${ }^{40} \mathrm{~K}$ in the samples varied of the order of about $10^{1}$ to $10^{3} \mathrm{~Bq} \mathrm{~kg}^{-1}$ more than ${ }^{238} \mathrm{U}$ and ${ }^{232} \mathrm{Th}$.

The high activity concentration of Potassium recorded for Lippia multiflora and Bridelia ferruginea can significantly aid in its therapeutic purposes for the treatment of High Blood Pressure since patients with High Blood Pressure have low concentration of Potassium in their blood stream (HBPI 2012). Although Bridelia ferruginea is used for the treatment of diabetes, almost all diabetic patients are hypertensive (Personal communication, Appiah A. A. 2012).

Published work in this field had involved other medicinal plants other than those considered for this study. However, comparing the results from this study with

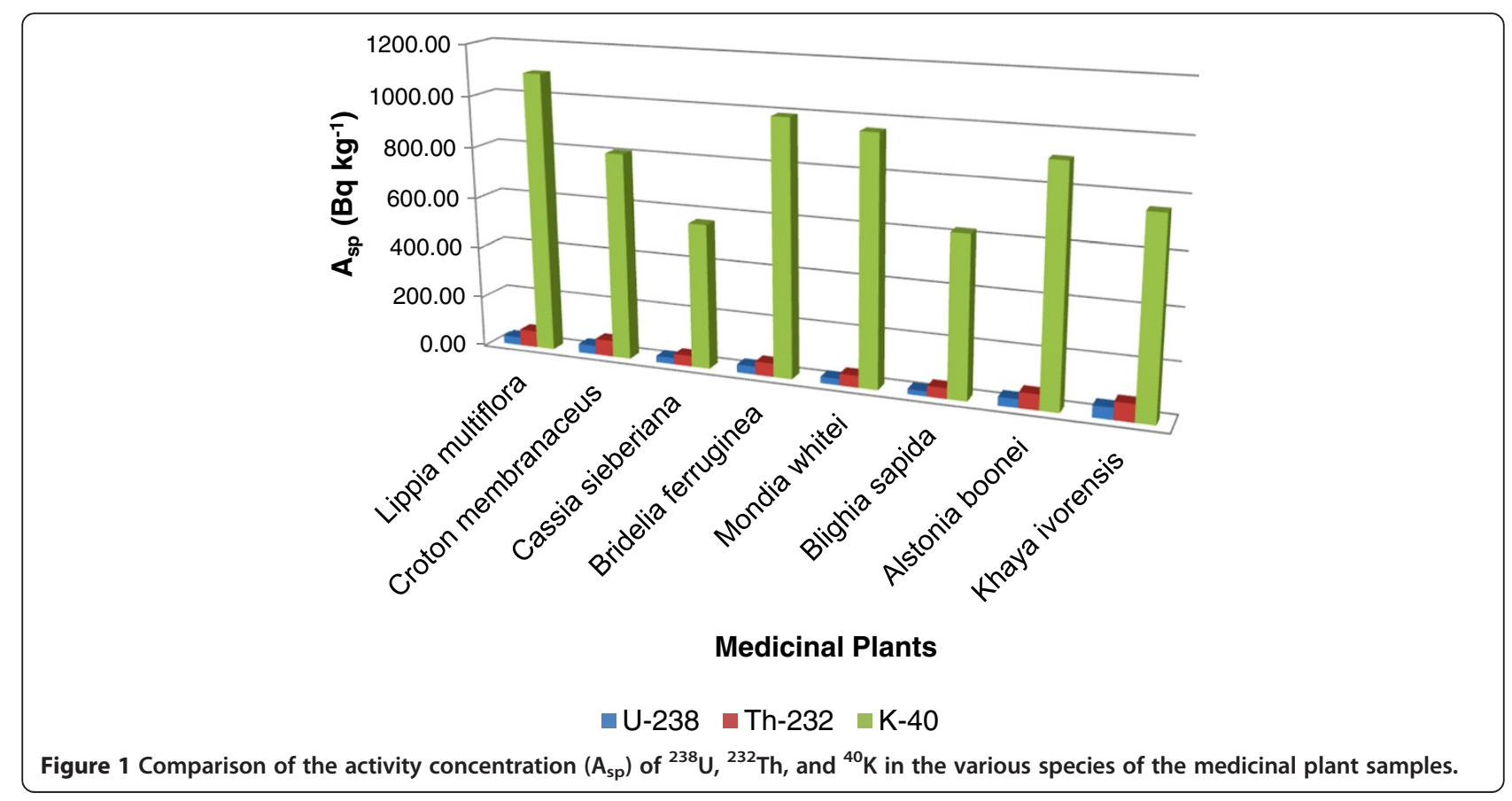


Table 3 Comparison of the activity concentration of ${ }^{238} \mathrm{U},{ }^{232} \mathrm{Th}$ and ${ }^{40} \mathrm{~K}$ in the medicinal plants from this study with those from other countries

\begin{tabular}{|c|c|c|c|c|c|c|c|}
\hline \multirow[t]{3}{*}{ Country } & \multicolumn{6}{|c|}{ Activity concentration ( $\mathrm{Bq} \mathrm{kg}^{-1}$ ) } & \multirow[t]{3}{*}{ Reference } \\
\hline & \multicolumn{2}{|c|}{${ }^{238} \mathrm{U}$} & \multicolumn{2}{|c|}{${ }^{232} \mathrm{Th}$} & \multicolumn{2}{|c|}{${ }^{40} \mathrm{~K}$} & \\
\hline & Range & Average & Range & Average & Range & Average & \\
\hline Ghana & $20.4-46.9$ & 31.8 & $42.0-70.6$ & 56.2 & $566.4-1093.1$ & 839.8 & This work \\
\hline Brazil & - & - & $<11.0-43.0$ & 21.7 & $666.0-1216.0$ & 976.3 & (Scheibel and Appoloni 2007) \\
\hline Italy & $<0.1-7.3$ & 0.4 & - & - & $5.4-3582.0$ & 654.7 & (Desideri et al. 2010) \\
\hline Nigeria & $14.7-16.2$ & 15.6 & $7.0-11.4$ & 8.5 & $66.8-70.2$ & 67.9 & (Olatunde et al. 2011) \\
\hline Serbia & $0.6-8.2$ & 2.6 & $1.7-15.1$ & 7.4 & $126.0-1243.7$ & 589.6 & (Jevremovic et al. 2011) \\
\hline
\end{tabular}

published data from some countries indicates that both the average activity concentration values obtained for ${ }^{238} \mathrm{U}$ and ${ }^{232} \mathrm{Th}$ in this study are higher than the other published work with the exception of ${ }^{40} \mathrm{~K}$ of which activity concentration from Brazil (Scheibel and Appoloni 2007) is higher than reported values in this study (Table 3).

The variations in the activity concentrations could be due to differences in the geological location of the plants and the radiochemical composition of the soils in which these medicinal plants are grown or cultivated since the levels of activity concentration of natural radionuclides are not normalized across the globe and the plants ability to absorb particular elements more than the others. The medicinal plants sampled for this study are located within the Mampong-Akuapem environs which is a mountainous forest area. It is therefore likely to exhibit high activity concentration of ${ }^{238} \mathrm{U}$ and ${ }^{232} \mathrm{Th}$ because of the presence of sedimentary and igneous rocks which are phosphate rich (IAEA 2003). The characteristics of the vegetation (forest area) of the area might have also contributed to the levels since the levels also depends on the soil organic matter content, soil to water ratio, site characteristics, rate and amount of rainfall, soil drainage and biochemical processes (Abu-Khadra and Eissa 2008). The high activity concentration of potassium present in the medicinal plants from Brazil (Scheibel and Appoloni 2007), the Mate tea, may be due to application of potassium containing fertilizers to the soil of cultivated area and/or the plant ability to absorb more potassium from the soil. High applications of potassium containing fertilizer are the cause of high activity concentration of ${ }^{40} \mathrm{~K}$ in most soil (Bhatti and Malik 1994). Since no potassium containing fertilizers were added to the soils of cultivation for Lippia multiflora and Bridelia ferruginea, the high activity concentration of potassium in these plants may be due to the plants ability to absorb potassium from the soil more than the other elements.

\section{Average annual committed effective dose in the medicinal plants}

The average annual committed effective doses due to the ingestion of ${ }^{238} \mathrm{U},{ }^{232} \mathrm{Th}$ and ${ }^{40} \mathrm{~K}$ in the medicinal plant are also presented in Table 2. The average annual committed effective dose of ${ }^{238} \mathrm{U},{ }^{232} \mathrm{Th}$ and ${ }^{40} \mathrm{~K}$ varied from $0.009 \pm 0.001$ to $0.014 \pm 0.002 \mathrm{mSv}^{-1}$ with an average of

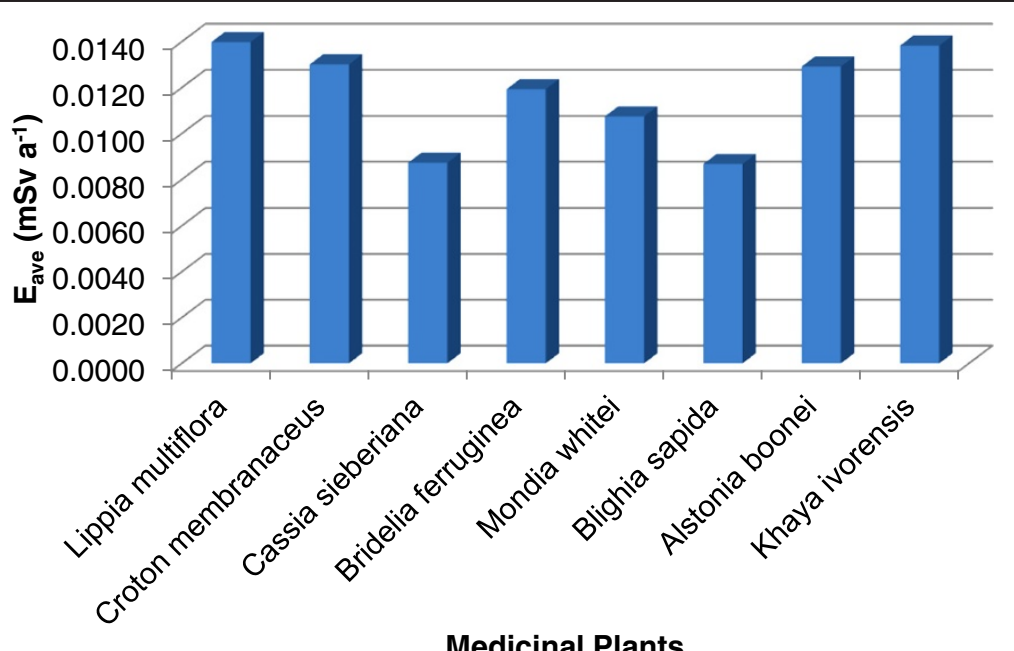

Figure 2 The average annual committed effective dose $\left(E_{\text {ave }}\right)$ distribution in the various species of the medicinal plant samples. 


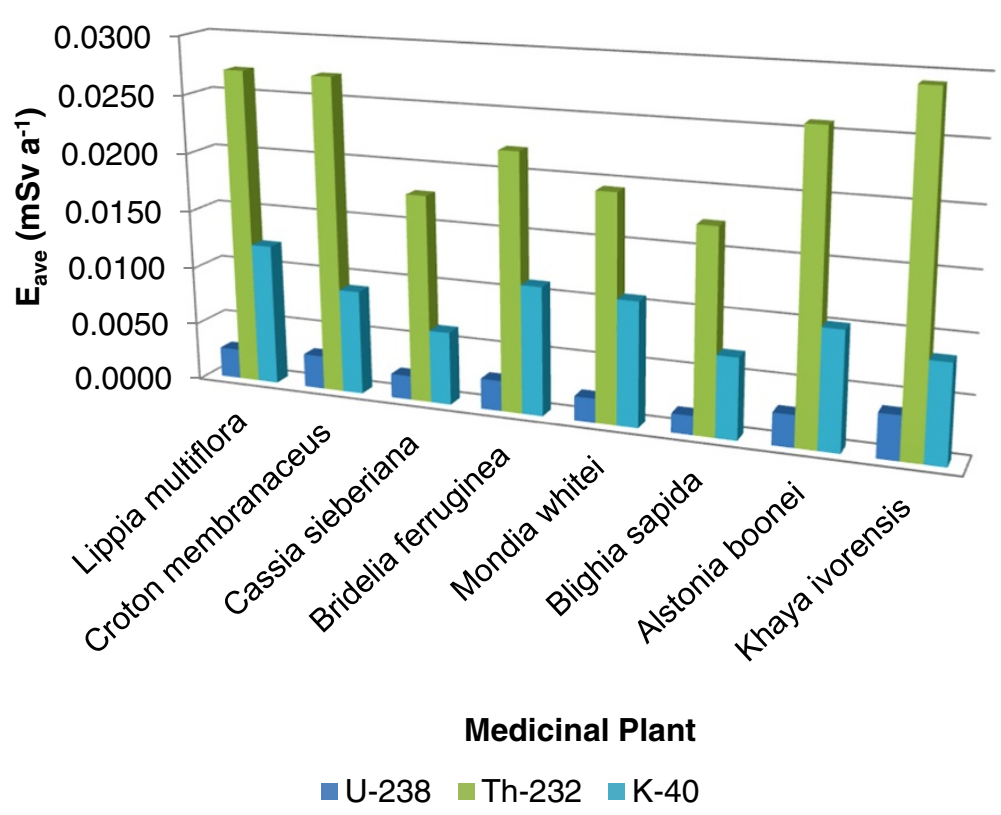

Figure 3 Comparison of the annual committed effective doses $\left(E_{a v e}\right)$ due to the natural radionuclides in the medicinal plant samples.

$0.012 \pm 0.001 \mathrm{mSv} \mathrm{a}^{-1}$. The highest average was recorded for Lippia multiflora whiles Cassia sieberiana and Blighia sapida have the lowest. Figure 2 shows the average annual committed effective dose distribution in the medicinal plant samples.

${ }^{232}$ Th contributes about $47 \%-70 \%$ to the average annual committed effective dose more than ${ }^{40} \mathrm{~K}$ and ${ }^{238} \mathrm{U}$ (Figure 3) although, the average annual committed effective dose due to ${ }^{238} \mathrm{U},{ }^{232} \mathrm{Th}$ and ${ }^{40} \mathrm{~K}$ for this study were relatively high compared to that which was reported for herbal tea in
Serbia (Jevremovic et al. 2011) as shown in Figure 4. This is due to the differences in the assumed consumption rate value of medicinal plants applied to this study and that from Serbia. Other factors may be geographical location of the plants, the plants ability to efficiently absorb certain natural radionuclide more than others and whether the plant was in their raw state or product forms which have a direct effect on the activity concentration.

However, the calculated average annual effective dose to any individual in the population group due to the

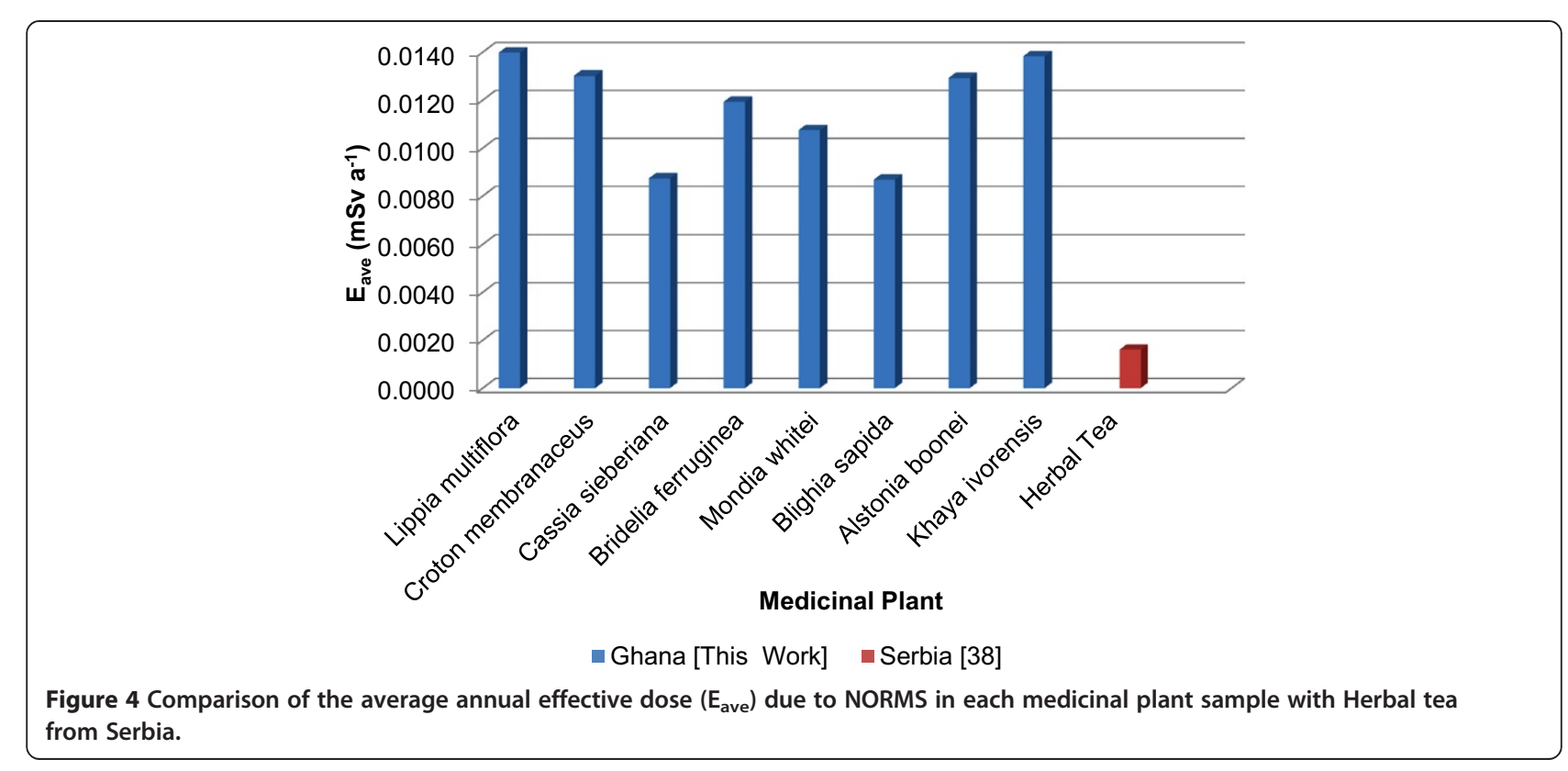


ingestion of natural radionuclides in the medicinal plants is far below the average radiation dose of $0.3 \mathrm{mSv} \mathrm{a}^{-1}$ received per head worldwide (UNSCEAR 2000).

\section{Conclusions}

Natural radioactivity levels of some selected medicinal plants commonly used in Ghana from the Centre for Scientific Research into Plant medicine were investigated using gamma-ray spectrometry.

The average activity concentration obtained for ${ }^{238} \mathrm{U}$ $\left(31.78 \pm 2.80 \mathrm{~Bq} \mathrm{~kg}^{-1}\right)$ and ${ }^{232} \mathrm{Th}\left(56.16 \pm 2.32 \mathrm{~Bq} \mathrm{~kg}^{-1}\right)$ in this study are higher compared to other published work with the exception of ${ }^{40} \mathrm{~K}\left(839.80 \pm 11.86 \mathrm{~Bq} \mathrm{~kg}^{-1}\right)$ which recorded a lower activity concentration compared to that recorded from Brazil (Scheibel and Appoloni 2007). Khaya ivorensis recorded the highest activity concentration of ${ }^{238} \mathrm{U}$ and ${ }^{232} \mathrm{Th}$ whilst Lippia multiflora recorded the highest activity concentration of ${ }^{40} \mathrm{~K}$. The high activity concentration of Potassium recorded in Lippia multiflora and Bridelia ferruginea can significantly aid in its therapeutic purposes in treating High Blood Pressure since patients with High Blood Pressure have low concentration of Potassium in their blood stream (HBPI 2012).

The corresponding average annual effective dose determined in this study to any individual's organ or tissue in the population group due to the ingestion of natural radionuclides in the medicinal plants is far below the average radiation dose of $0.3 \mathrm{mSv}^{-1}$ received per head worldwide due to the ingestion of natural radionuclide (UNSCEAR 200). The result presents insignificant annual committed effective dose due to the use of these medicinal plants in Ghana from the Centre for Scientific Research into Plant Medicine. Therefore the radiological hazard associated with intake of the natural radionuclides in the medicinal plants is insignificant. Hence, the medicinal plants samples from the Centre are considered safe in terms of the radiological hazard.

\section{Competing interests}

All authors declare no financial competing interests.

\section{Authors' contributions}

Lordford Tettey-Larbi carried out the experimental work and prepared the manuscript, Alfred Ampomah Appiah provided the physical data of the medicinal plants and all authors read and approved the final manuscript.

\section{Acknowledgements}

The authors would like to acknowledge with thanks the assistance received from the management of Centre of Scientific Research into Plant Medicine during the period of sampling and also providing information on each medicinal plant. The authors are also grateful to the Radiation Protection Institute (RPI) of the Ghana Atomic Energy Commission for making their laboratories available for the research. The authors also appreciate the contribution of Mr. Poku-Awiah Kwame of CSRPM and Mr. D. O. Kpeglo, Mr. Oscar Adukpo, Mr. Henry Lawluvi, Mr. Charles Kansaana, Ms. Rita Kpordzro and Mr. Ibrahim Doe Ali all of RPI for their assistance in the completion of this work.

\section{Author details}

${ }^{1}$ Graduate School of Nuclear and Allied Sciences, University of Ghana, P. O. Box AE 1, Atomic Energy, Kwabenya, Accra, Ghana. ${ }^{2}$ Radiation Protection Institute, Ghana Atomic Energy Commission, Box LG 80, Legon, Accra, Ghana. ${ }^{3}$ Centre for Scientific Research into Plant Medicine, P. O. Box 73,

Mampong-Akuapem, Ghana.

Received: 1 November 2012 Accepted: 1 April 2013

Published: 11 April 2013

\section{References}

Abu-Khadra SA, Eissa HS (2008) Natural radionuclides in different plants, together with their corresponding soils in Egypt at Inshas region and the area nearby, IX radiation physics \& protection conference., Nasr city - Cairo, National Network of Radiation Physics-Egyptian Atomic Energy Authority, pp 239-249

Adewumi AA (2011) Assessment of norm-containing food crops/stuffs in OML 58 \& OML 61 within the Niger delta region of Nigeria Proceedings of the 1st international technology, education and environment conference, African society for scientific research (ASSR), pp 594-603

ANL (2005) Potassume-40 Argonne national laboratory, EVS, human health fact sheet

Bhatti TM, Malik KA (1994) Phosphate fertilizers a potential source for uranium recovery as by product, National institute for biotechnology and genetic engineering (NIBGE), Faisalabad Pakistan, Technical report no PAEC/NIBGE-2/ 1994

Brown K (1992) Medicinal plants, indigenous medicine and conservation of biodiversity in Ghana. Centre for Social and Economic Research on Global Environment (CSERGE), Norwich, UK, working paper GEC:92-36

Cember H, Johnson TE (2009) Introduction to health physics Fourth edition. McGraw-Hill Companies, Inc., USA

Changizi V, Jafarpoor Z, Naseri M (2010) Measurement of ${ }^{226} \mathrm{Ra}^{228}{ }^{22} \mathrm{Ra}$, ${ }^{137} \mathrm{Cs}$ and ${ }^{40} \mathrm{~K}$ in edible parts of two types of leafy vegetables cultivated in Tehran province-Iran and resultant annual ingestion radiation dose. Iran J Radiat Res 8(2):103-110

CSRPM (2011) Homepage website Retrieved $16^{\text {th }}$ September, 2011, from the World Wide: http://www.csrpm.org

Cuttler JM (2004) What becomes of nuclear risk assessment in light of radiation hormesis? Proceedings of the $25^{\text {th }}$ annual conference of the Canadian nuclear society. Canadian Nuclear Society, Toronto

Desideri D, Meli MA, Roselli C (2009) Determination of essential and non-essential element in some medicinal plants by polarized. X ray fluoresc spectrometer Microchem J 95(2010):174-180. doi:10.1016/j.microc.2009.11.010

Desideri D, Meli MA, Roselli C (2010) Natural and artificial radioactivity determination of some medicinal plants. Journal of environmental radioactivity 101:751-756. doi:10.1016/j.jenvrad.2010.04.018

Ebaid YY (2010) Use of gamma-ray spectrometry for uranium isotopic analysis of environmental samples. Rom Journ Phys 55(1-2):69-74

Gilmore G, Hemingway JD (1995) Practical Gamma Spectrometry. John Wiley and Sons, NY, NY

Google Earth (2012) Google Earth software programmeme Retrieved from the internet based software Google Earth version 6.1.0.5001., on 26 ${ }^{\text {th }}$ January, 2012

Gurib-Fakim A, Kasilo OMJ (2010) African medicinal plants through an African herbal pharmacopoeia The African health monitor, African traditional medicine day. Special issue 14:64-77

Haq I (2004) Safety of medicinal plants Review Article Pakistan. J Med Res 43(No. 4)

HBPI (2012) Food high in Potassium High Blood Pressure Information., Retrieved March 29, 2012 from the World Wide Web: http:/www.highbloodpressure info.org/food-high-in-potassium.html

HPS (2004) Radiation risk in perspective, position statement of the health physics society Health physics society. Retrieved on December 17, 2011 from the World Wide Web: http://www.hps.org/documents/radiationrisk.pdf

IAEA (2003) Extent of environmental contamination by naturally occurring radioactive material (NORM) and technological options for mitigation Technical Repost Series No. 419. International Atomic Energy Agency, Vienna

IAEA (2006) Classification of soil systems on the basis of transfer factors of radionuclides from soil to reference plants IAEA-TECDOC 1497. IAEA, Vienna

ICRP (1991) 1990 recommendations of the international commission on radiological protection, Internal commission on radiological protection ICRP publication 60 Annals of the ICRP 21(1-3). Pergamon press, oxford

ICRP (2005) Biological and epidemiological information on health risks attributable to ionising radiation: a summary of judgments for the purposes 
of radiological protection of humans International Commission on Radiological Protection committee 1 Task Group report: c1 foundation document (fd-c-1). Pergamon press, Oxford

INFOSAN (2011) Information on nuclear accidents and radioactive contamination of foods International Food Safety Authorities Network. World Health Organization (WHO), Geneva

Jevremovic M, Lazarevic N, Pavlovic S, Orlic M (2011) Radionuclide concentrations in samples of medicinal herbs and effective dose from ingestion of ${ }^{137} \mathrm{Cs}$ and natural radionuclides in herbal tea products from. Serbian market Isotopes Environ Health Studies 47(1):87-92. doi:10.1080/10256016.2011.556723

Kamboj VP (2000) Herbal medicine. Curr Sci 78(1-10):35-51

Kessaratikoon P, Awaekechi S (2008) Natural radioactivity measurement in soil samples collected from municipal area of Hat Yai district in Songkhla province, Thailand. KMITL Sci J Section A 8(2):52-58

Miah FK, Roy S, Touhiduzzaman N, Alan B (1998) Distribution of radionuclides in soil samples in an around. Dhaka city Appl Radiat Isot 49(1-2):133-137

Mukhammedov S, Tillaeva K (2005) Natural. Radioac some med plants J Nucl Radiat Physics 1(1):73-76

Olatunde MO, Gbadebo Al, Funmi GOO, Olusegun S (2011) Natural activity concentration and assessment of radiological dose equivalents in medicinal plants around oil and gas facilities in Ughelli and environs. Nigeria Environ Nat Resour Res 1(1):201-206. doi:10.5539/enrr.v1n1p201

Oresengun MO, Decker KM, Sanderson CG (1993) Determination of Self Absorption Correction by Computation in routine Gamma-ray Spectrometry for Typical Environmental Samples. J Radioact Radiochem 4:38-45

Owusu-Afriyie G (2005) Conserving medicinal plants in Ghana. Current issue: Traditional plants ICT update Issue no. 26., Retrieved October 11, 2011 from the World Wide Web: http://ictupdate.cta.int/en/content/view/full/787

Scheibel V, Appoloni CR (2007) Survey of natural radioactivity levels in lles paraguariensis (St. Hil.) by. Gamma-ray spectrom Braz Archives Biology Technology 50(5):901-904

Serfor-Armah Y, Akaho EHK, Nyarko BJB, Kyere AWK, Oppon-Boachie K (2003) Application of instrumental neutron activation analysis to plant medicine in Ghana. A rev J Radioanalytical Nuclear Chem 257(1):125-128

Serfor-Armah Y, Nyarko BJB, Akaho EHK, Kyere AWK, Osae S, Oppon-Boachie K Osae EK (2001) Activation analysis of some essential elements in five medicinal plants used in. Ghana J Radioanalytical Nucl Chem 250(1):173-176

Tahir SNA, Alaamer AS (2008) Determination of natural radioactivity in rock salt and radiation doses due to its ingestion Journal of Radiological Protection. Vol 28:233-236

Tahir SNA, Alaamer AS (2009) Concentrations of natural radionuclides in municipal supply drinking water and evaluation of radiological hazards Environmental Forensics. Vol 10:1-6

Tahir SNA, Alaamer AS, Ayub M, Khan MZ (2010) Radiometric Analysis of Samples of Domestic Fish Species and Radiological Implications Health Physics. Vol 98:741-744

UNSCEAR (1988) Sources and effects of ionising radiation United Nations Scientific Committee on the Effects of Atomic Radiation. United Nations, New York

UNSCEAR (2000) Sources and effects of ionising radiation United Nations Scientific Committee on the Effects of Atomic Radiation. United Nations, New York

WHO (1991) Progress report by the director general, document No. A44/20, 22. World Health Organisation, Geneva

WHO (1998) Regulatory situation of herbal medicine: A worldwide review. World Health Organisation, Geneva

doi:10.1186/2193-1801-2-157

Cite this article as: Tettey-Larbi et al: Natural radioactivity levels of some medicinal plants commonly used in Ghana. SpringerPlus 2013 2:157.

\section{Submit your manuscript to a SpringerOpen ${ }^{\circ}$ journal and benefit from:}

- Convenient online submission

- Rigorous peer review

- Immediate publication on acceptance

- Open access: articles freely available online

- High visibility within the field

- Retaining the copyright to your article

Submit your next manuscript at $\gg$ springeropen.com 